\title{
SELF-ESTEEM REMAJA AWAL: TEMUAN BASELINE DARI RENCANA PROGRAM SELF-INSTRUCTIONAL TRAINING KOMPETENSI DIRI
}

\author{
Dilla Tria Febrina, Puji Lestari Suharso, Airin Yustikarini Saleh \\ Fakultas Psikologi, Universitas Indonesia \\ E-mail:dillatriafebrina@gmail.com,pprianto@ui.ac.id,airin.yustikarini@ui.ac.id
}

\begin{abstract}
This research aimed to obtain baseline data as the first stage of preparation of selfinstructional training programs as an intervention for early adolescents who had self-esteem problems. The participant in this study was a teenage boy who has a negative self-evaluation related to self-competence at school. The design in this research was single-subject, with A1-A2-A3 design. Measurement of self-esteem in this study was interview techniques on the participant, significant other, and teachers among three different situations. The instrument was developed based on high self-esteem characteristics of Rosenberg and Owens (Guindon, 2010). The results of this study indicated that the boy had low self-esteem related to selfcompetence and affected to important areas of development such as academic. Based on this study, further researchs was necessary to develope an intervention that solved the problems of self-esteem in early adolescence.
\end{abstract}

Key words: self-esteem, early adolescence, baseline

\begin{abstract}
Abstrak
Penelitian ini bertujuan untuk memperoleh data baseline sebagai tahapan pertama dari rencana penyusunan program self-instructional training sebagai intervensi untuk remaja awal yang mengalami masalah dalam self-esteem. Subjek dalam penelitian ini adalah seorang remaja laki-laki yang memiliki penilaian diri yang negatif terkait kompetensi diri di sekolah. Desain penelitian yang digunakan dalam penelitian ini adalah single-subject design, dengan desain A1-A2-A3. Pengukuran self-esteem dalam penelitian ini menggunakan teknik wawancara pada subjek, significant other, dan guru pada tiga kondisi yang berbeda. Instrumen pengukuran disusun berdasarkan karakteristik self-esteem tinggi menurut Rosenberg dan Owens (Guindon, 2010). Hasil dari penelitian ini menunjukkan bahwa remaja awal laki-laki memiliki self-esteem rendah yang berkaitan dengan kompetensi diri dan berdampak pada area penting dalam perkembangannya seperti akademis. Dengan diperolehnya hasil penelitian ini dapat dikatakan bahwa dalam penelitian lebih lanjut diperlukan suatu rancangan intervensi yang dapat dikembangkan untuk menangani permasalahan self-esteem yang terjadi pada remaja awal.
\end{abstract}

Kata kunci: self-esteem, remaja awal, baseline

\section{PENDAHULUAN}

Self-esteem merupakan evaluasi seseorang dalam menilai dirinya sendiri, yakni seberapa puas seseorang dengan dirinya sendiri (Johnson, dalam Sveningson, 2012). 
Perkembangan self-esteem (baik itu global self-esteem maupun selective self-esteem) pada individu dimulai sejak masa kanak-kanak hingga dewasa, hanya saja mengalami penurunan pada masa remaja (Bos, Muris, Mulkens, \& Schaalma, 2006). Penurunan global self-esteem yang drastis pada remaja berkaitan dengan fase storm dan stress selama masa remaja yang ditunjukkan dengan adanya perubahan secara biologis, kognitif, sosial, psikologis, maupun akademis (Robins et al, dalam Bos, Muris, Mulkens, \& Schaalma, 2006).

Selain itu, peningkatan kemampuan kognitif yang dialami remaja juga berkaitan dengan tugas perkembangan sosio-emosionalnya yang memasuki tahap identity vs confusion (Erikson, dalam Guindon, 2010). Pada tahap ini, remaja berusaha menjawab pertanyaan mengenai "Siapa dirinya?" dan bagaimana menunjukkan diri sesuai dengan identitas dirinya. Hal ini karena pada tahap ini remaja merasa bahwa menampilkan citra diri (self-image) merupakan hal yang penting, misalnya dalam hal penampilan, kegiatan, atau melakukan perbandingan dengan orang dewasa yang sangat dikagumi. Dengan adanya tugas perkembangan sosio-emosional tersebut, remaja mulai memiliki kesadaran diri dan fokus terhadap dirinya sendiri (Marotz dan Allen, 2013). Harter (Guindon, 2010; Chung, Hutteman, Aken, \& Denissen, 2017) mengemukakan bahwa adanya kesadaran diri dan peningkatan kapasitas untuk melakukan refleksi diri membuat remaja merasa adanya perbedaan antara actual-self dan ideal-self. Adanya diskrepansi antara actual-self dan ideal-self ini berdampak pada penurunan self-esteem remaja.

Tingkat self-esteem individu dapat dilihat dari beberapa karakteristik yang ditunjukkan oleh individu tersebut. Rosenberg dan Owens (Guindon, 2010) mengemukakan bahwa individu yang memiliki self-esteem tinggi menunjukkan dirinya sebagai pribadi yang optimis; bangga dan puas akan dirinya sendiri; lebih sensitif terhadap tingkat kemampuan/kompetensi, mengabaikan umpan balik negatif dan mencari umpan balik mengenai kompetensi; menerima peristiwa negatif yang dialami dan berusaha memperbaiki diri; lebih sering mengalami emosi positif (senang, bahagia); fleksibel, berani, dan lebih mampu mengekspresikan diri saat berinteraksi dengan orang lain (spontan dan aktif); berusaha untuk melakukan sesuatu agar kapasitas dirinya meningkat (lebih tumbuh dan berkembang); berani mengambil resiko; bersikap positif terhadap orang lain, kelompok, atau institusi; berpikir konstruktif (fleksibel); mampu mengambil keputusan dengan cepat dan yakin dengan keputusan yang diambilnya.

Sebaliknya, remaja dengan self-esteem rendah cenderung menunjukkan karakteristik seperti pesimis; tidak puas akan dirinya, berkeinginan untuk menjadi orang lain atau berada di posisi orang lain; lebih sensitif terhadap pengalaman yang akan merusak harga dirinya (terganggu oleh kritik orang lain dan lebih emosional saat mengalami kegagalan); cenderung melihat peristiwa sebagai hal yang negatif (membesar-besarkan peristiwa negatif yang dialami); cenderung mengalami kecemasan sosial dan lebih sering mengalami emosi negatif; canggung, pemalu, dan tidak mampu mengekspresikan diri saat 
berinteraksi dengan orang lain (kurang spontan dan lebih pasif); melindungi diri dan tidak berani melakukan kesalahan; menghindari pengambilan resiko; sinis dan memiliki sikap negatif terhadap orang lain, kelompok, atau institusi; pemikiran cenderung tidak konstruktif (kaku dan tidak fleksibel); serta cenderung ragu-ragu dan lebih lambat untuk merespon saat mengambil keputusan.

Tinggi rendahnya self-esteem remaja dipengaruhi oleh tiga komponen penting yang terlibat dalam proses evaluasi dirinya, yakni umpan balik dari significant others; pengetahuan tentang siapa dirinya dan perasaan terhadap identitas dirinya, value yang dimiliki, keyakinan akan value pribadi; serta kesadaran akan tingkat kompetensi dan mengapresiasi prestasinya (Guindon, 2010; Harter, dalam Bos, Muris, Mulkens, \& Schaalma, 2006). Sejalan dengan komponen tersebut, Mruk (2006) juga berpendapat bahwa terdapat beberapa faktor eksternal yang dapat mempengaruhi self-esteem remaja, yakni faktor keluarga (baik itu dukungan dan keterlibatan orang tua, kehangatan orang tua, harapan dan konsistensi orang tua, pola asuh, dan modeling), gender, ras, etnis, status sosio-ekonomi, dan value sosial.

Berkaitan dengan faktor gender, Harter (Mruk, 2006) mengemukakan bahwa penurunan self-esteem selama masa remaja mempengaruhi kedua jenis kelamin. Hanya saja, self-esteem remaja perempuan lebih terkait dengan kepuasan untuk diterima dan dihargai secara emosional terutama terkait dengan penampilan fisiknya, sedangkan selfesteem remaja laki-laki lebih berkaitan dengan perkembangan kompetensi yang ditunjukkan melalui pencapaian atau prestasi. Jika faktor eksternal ini mempengaruhi self-esteem remaja menjadi rendah maka akan memunculkan faktor internal yang juga turut berpengaruh didalamnya yakni adanya pemikiran distorsi, seperti overgeneralization, global labelling, filtering, polarized thinking, self-blame, personalization, mind reading, control fallacies, dan emotional reasoning (Mc Kay \& Fanning, 2016).

Mann, dkk (Donders \& Verschueren; Bos, Muris, Mulkens, \& Schaalma, 2006) mengemukakan bahwa problem self-esteem pada remaja sangat krusial karena berdampak pada beberapa aspek penting dalam perkembangan remaja, seperti prestasi akademik, fungsi hubungan sosial, bahkan psikopatologi pada anak dan remaja. Sehubungan dengan area akademis, berbagai penelitian menunjukkan bahwa remaja dengan self-esteem rendah cenderung kurang berhasil secara akademis di sekolah. Soufi, Damirchi, Sedghi, dan Sabayan (2013) dalam penelitiannya mengemukakan bahwa para siswa yang memiliki keyakinan positif tentang dirinya merasa memiliki kompetensi yang lebih tinggi pada bidang akademik.

Baldwin dan Hoffman (Guindon, 2010) mengemukakan bahwa remaja dengan selfesteem rendah sejak masa kanak-kanak mengalami banyak kesulitan pada masa remaja dan mengalami perasaan tidak mampu pada banyak bidang. Selain itu, berkaitan dengan fungsi hubungan sosial, penelitian menunjukkan bahwa remaja dengan self-esteem rendah biasanya kurang diterima oleh teman-temannya. McClure (2010) mengemukakan bahwa 
remaja dengan self-esteem rendah juga cenderung berperilaku mencari perhatian dari orang lain. Akhirnya, banyak penelitian yang telah menunjukkan bahwa self-esteem yang rendah berhubungan dengan psikopatologis remaja, termasuk kecemasan, depresi, dan gangguan makan (Bos, Muris, Mulkens, \& Schaalma, 2006). Oleh karena itu, mengingat problem self-esteem yang terjadi pada remaja ini sangat berdampak pada pencapaian tugas perkembangannya maka intervensi terhadap remaja yang memiliki self-esteem rendah sangat penting untuk segera dilakukan. Menurut Guindon (2010), permasalahan self-esteem yang tidak segera ditangani pada masa remaja akan menyebabkan individu tidak mengetahui value pribadi, tidak mengetahui sejauh mana kapasitasnya, sehingga ia tidak mampu menjawab siapa dirinya dan bagaimana rencana masa depannya pada masa dewasa.

Martin dan Pear (2015) mengatakan bahwa jika kita ingin menyusun suatu program intervensi (program modifikasi perilaku) yang berhasil, maka akan melibatkan empat fase selama perilaku target diidentifikasi, didefinisikan, dan dicatat yakni (1) fase screening, (2) fase preprogram atau baseline, (3) fase treatment, dan (4) fase follow up. Pada artikel ini, akan dibahas fase baseline yang merupakan fase preporgram. Fase ini perlu dipersiapkan dengan baik karena sebagaimana dikemukakan oleh Martin dan Pear (2015), tujuan dari fase ini adalah untuk menilai dan menentukan tingkat target perilaku yang ingin diubah sebelum diperkenalkannya program modifikasi perilaku.

Martin dan Pear (2015) mengemukakan enam alasan pentingnya data baseline yang dirumuskan secara akurat, yaitu 1) adanya data baseline yang akurat membantu peneliti untuk menentukan desain/program intervensi yang cocok dan sesuai dengan subjek penelitian; 2) baseline yang akurat juga kadang memunculkan masalah lain sehingga dapat mempengaruhi rancangan program intervensi yang akan diberikan; 3) baseline yang akurat membantu peneliti menemukan penyebab dari perilaku dan menentukan strategi intervensi terbaik; 4) data baseline yang akurat mampu menunjukkan proses perubahan perilaku selama program berlangsung; 5) data baseline yang akurat yang digambarkan dalam bentuk tabel akan mempermudah peneliti dan subjek untuk melihat hasil awal kondisi subjek sebelum diberikan program modifikasi perilaku, serta 6) data baseline dapat digunakan untuk mengembangkan keilmuan atau program intervensi lain yang serupa. Pada fase baseline dalam penelitian ini, peneliti mengukur tingkat selfesteem partisipan melalui wawancara karakteristik self-esteem tinggi menurut Rosenberg dan Owens (Guindon, 2010).

\section{METODE}

\section{Partisipan}

Pemilihan subjek dalam penelitian ini menggunakan teknik purposive sampling yaitu subjek dipilih berdasarkan karakteristik yang dimiliki oleh subjek dan sesuai dengan 
tujuan dari penelitian (Shadish, Cook, \& Thomas, 2002). Teknik ini merupakan bagian dari nonprobability sampling. Dalam penelitian ini, subjek yang terpilih adalah remaja laki-laki berusia 12 tahun dan sedang duduk di kelas VI. Awalnya, subjek dirujuk oleh pihak sekolah untuk mengikuti pemeriksaan psikologis karena perilakunya yang kurang baik di sekolah, seperti berbicara kasar, jahil terhadap teman, tidak mengerjakan tugas pada beberapa pelajaran sehingga prestasi akademisnya berada di bawah rata-rata prestasi teman sekelasnya. Hasil pemeriksaan psikologis menunjukkan bahwa subjek memiliki kecerdasan yang berada pada taraf Rata-rata ( $\mathrm{IQ}=104$, menurut skala Wechsler). Berdasarkan kemampuan intelektualnya ini, subjek memiliki potensi yang baik dalam memahami beragam materi dan dapat berprestasi di sekolah. Hanya saja, potensi yang dalam diri subjek tidak sesuai dengan perilaku belajar dan prestasinya di sekolah. Ia mendapat ranking 29 dari 33 siswa di kelasnya.

Dalam lingkungan keluarga, subjek adalah anak pertama dari dua bersaudara yang hidup terpisah karena orangtuanya bercerai. Awalnya subjek diasuh oleh nenek kemudian oleh paman dan bibinya. Adanya perpindahan pengasuhan dari orangtua, nenek, serta paman dan bibinya membuat subjek memperoleh pola asuh yang berbeda-beda [orangtua (neglectful parenting), nenek (indulgent parenting), paman dan bibinya (authoritarian)]. Dampak dari perbedaan pola asuh membuat subjek tampil sebagai remaja yang kurang mampu mengontrol diri, tidak cukup mandiri, dan tidak termotivasi untuk berprestasi di sekolah. Subjek juga tampil sebagai remaja yang kurang kompeten dalam menjalin interaksi sosial.

\section{Desain Penelitian}

Penelitian ini menggunakan single-subject design karena peneliti tidak melakukan randomisasi subjek ke dalam kelompok penelitian (Bordens \& Abott, 2011). Selain itu, dalam desain single subject design peneliti melakukan penilaian berulang terhadap suatu fenomena tertentu dari waktu ke waktu (Lee, 2005). Hal ini sesuai dengan tujuan penelitian yakni mengukur tingkat self-esteem subjek sebelum diberikannya program intervensi. Kategori desain yang digunakan dalam penelitian ini adalah desain A1-A2-A3.

\section{Asesmen}

Proses asesmen dalam penelitian ini dilakukan sebanyak tiga kali. Hal ini dilakukan untuk meningkatkan validitas penelitian, peneliti melakukan pengukuran dan pencatatan data pada kondisi baseline (A) secara kontinu sekurang-kurangnya 3 atau 5 kali atau sampai trend dan level data diketahui secara jelas (Sunanto, Takeuchi, \& Nakata, 2005). Dalam penelitian ini, instrumen pengukuran yang digunakan oleh peneliti adalah pengukuran kualitatif melalui metode wawancara. Instrumen panduan wawancara disusun berdasarkan karakteristik individu dengan self-esteem tinggi menurut Rosenberg dan Owens (Guindon, 2010). 
Pada penelitian ini, peneliti menentukan indikator keberhasilan dari wawancara mengenai karakteristik self-esteem tinggi menurut Rosenberg dan Owens (dalam Guindon, 2010). Pengukuran ini dilakukan untuk memperoleh gambaran secara kualitatif mengenai perubahan tingkat self-esteem yang dialami subjek selama fase baseline dengan cara membandingkan respon jawaban subjek terhadap item-item pertanyaan yang diberikan. Selain itu, berdasarkan sebelas karakteristik self-esteem tinggi menurut Rosenberg dan Owens (Guindon, 2010), peneliti menentukan kategori tingkat self-esteem subjek sebagai berikut:

1. Jika subjek berhasil mencapai 9 hingga 11 karakteristik self-esteem tinggi maka self-esteem subjek tergolong tinggi.

2. Jika subjek berhasil mencapai 5 hingga 8 karakteristik self-esteem tinggi maka self-esteem subjek tergolong sedang.

3. Jika subjek berhasil mencapai 1 hingga 4 karakteristik self-esteem tinggi maka self-esteem subjek tergolong rendah.

\section{Prosedur}

Tahap persiapan penelitian ini disebut fase screening yaitu interaksi awal antara peneliti dan subjek, wali, dan guru (Martin \& Pear, 2015). Peneliti melakukan analisis kebutuhan dimulai dari membangun rapport dengan subjek, meminta kesediaan subjek, wali, dan guru untuk mengikuti asesmen, meminta wali untuk mengisi inform consent sebagai izin formal bahwa subjek diizinkan mengikuti rangkaian penelitian, melakukan pemeriksaan psikologis terhadap subjek, serta melakukan wawancara pada subjek, wali, dan guru untuk memperoleh gambaran umum permasalahan yang dialami oleh subjek.

Tujuan tahap persiapan ini adalah untuk memberitahu subjek dan wali mengenai gambaran prosedur penelitian serta memperoleh informasi yang cukup untuk mendiagnosis subjek, dan memperoleh informasi spesifik mengenai target perilaku yang perlu dilakukan penilaian. Setelah memperoleh gambaran umum permasalahan yang dialami subjek, peneliti melakukan tinjauan literatur untuk menentukan perilaku target yang akan diukur pada fase baseline yakni mengenai self-esteem subjek. Setelah itu, peneliti menyusun indikator dan pertanyaan wawancara berdasarkan karakteristik self-esteem tinggi menurut Rosenberg dan Owens (Guindon, 2010).

Pada tahap pelaksanaan, disebut juga fase baseline yakni tahap dimana peneliti melakukan pengukuran mengenai target perilaku yang dilakukan pada kondisi natural sebelum subjek diberikan intervensi (Martin \& Pear, 2015). Pada tahap ini peneliti memasuki fase baseline dengan melakukan wawancara pada subjek, wali, dan wali kelas subjek. Tujuan tahap ini untuk menilai dan menentukan tingkat target perilaku yang ingin diubah sebelum diperkenalkannya program intervensi. Wawancara dilakukan di rumah setelah subjek pulang dari sekolah. Peralatan yang digunakan dalam pelaksanaan fase baseline ini adalah panduan wawancara, recorder, dan alat tulis. Proses pelaksanaan 
pengambilan baseline ini dilakukan sebanyak tiga kali dalam waktu yang berbeda, yakni saat subjek duduk di kelas 5 dan 6 yakni pada bulan Februari, Maret, dan Agustus 2017. Pengambilan data baseline yang dilakukan sebanyak tiga kali ini karena untuk meningkatkan validitas penelitian ini, pada baseline pertama dan kedua trend atau level data belum diketahui dengan jelas yakni masih ada beberapa karakteristik yang tidak terukur.

Selanjutnya, tahap analisis yaitu tahap mengurai dan mengolah data mentah menjadi data yang dapat ditafsirkan dan dipahami secara lebih spesifik dan diakui dalam suatu prospektif ilmiah yang sama (Herdiansyah, 2012). Tahap analisis ini merupakan tahap pengolahan data terakhir sebelum peneliti menarik kesimpulan mengenai kondisi selfesteem subjek. Dalam penelitan ini, analisis dilakukan dengan cara membandingkan kondisi self-esteem subjek berdasarkan jawaban subjek, wali, dan wali kelas subjek saat baseline pertama, kedua, dan ketiga.

\section{HASIL}

Peneliti membandingkan perubahan jawaban subjek, wali, dan, guru saat wawancara terkait karakteristik self-esteem tinggi menurut Rosenberg dan Owens (dalam Guindon, 2010). Berdasarkan hasil baseline pertama, terdapat enam karakteristik self-esteem tinggi yang tidak tercapai pada diri subjek, yakni optimis; bangga dan puas akan dirinya sendiri; lebih sering mengalami emosi positif (senang, bahagia); fleksibel, berani, dan lebih mampu mengekspresikan diri saat berinteraksi dengan orang lain (spontan dan aktif); berusaha untuk melakukan sesuatu agar kapasitas dirinya meningkat (lebih tumbuh dan berkembang); dan bersikap positif terhadap orang lain, kelompok, atau institusi. Pada baseline pertama lima karakteristik lainnya yang tidak terukur dalam baseline pertama adalah lebih sensitif terhadap tingkat kemampuan/kompetensi; mengabaikan umpan balik negatif dan mencari umpan balik mengenai kompetensi; menerima peristiwa negatif yang dialami dan berusaha memperbaiki diri; berani mengambil resiko; berpikir konstruktif (fleksibel); dan mampu mengambil keputusan dengan cepat dan yakin dengan keputusan yang diambilnya.

Pada baseline kedua, terdapat enam karakteristik yang tidak tercapai pada diri subjek, yakni optimis, lebih sensitif terhadap tingkat kemampuan/kompetensi; mengabaikan umpan balik negatif dan mencari umpan balik mengenai kompetensi; lebih sering mengalami emosi positif (senang, bahagia); fleksibel, berani, dan lebih mampu mengekspresikan diri saat berinteraksi dengan orang lain (spontan dan aktif); berani mengambil resiko; dan mampu mengambil keputusan dengan cepat dan yakin dengan keputusan yang diambilnya. Dalam baseline kedua, terdapat lima karakteristik lainnya yang tidak terukur yakni bangga dan puas akan dirinya sendiri; menerima peristiwa negatif yang dialami dan berusaha memperbaiki diri; berusaha untuk melakukan sesuatu 
agar kapasitas dirinya meningkat (lebih tumbuh dan berkembang); bersikap positif terhadap orang lain, kelompok, atau institusi; dan berpikir konstruktif (fleksibel).

Tabel 1

Hasil pengambilan baseline I, II, III

\begin{tabular}{|c|c|c|c|}
\hline $\begin{array}{c}\text { Karakteristik } \\
\text { Self-esteem Tinggi }\end{array}$ & $\begin{array}{c}\text { Baseline I } \\
((+) \text { : Tercapai, } \\
\text { (-) : Tidak } \\
\text { tercapai) }\end{array}$ & $\begin{array}{c}\text { Baseline } \text { II } \\
((+) \text { : Tercapai, } \\
\text { (-): Tidak tercapai) }\end{array}$ & $\begin{array}{c}\text { Baseline III } \\
((+): \text { Tercapai, } \\
(-): \text { Tidak tercapai })\end{array}$ \\
\hline Optimis. & $\begin{array}{l}\text { (-) merasa tidak } \\
\text { kompeten dalam } \\
\text { pelajaran Bahasa } \\
\text { Inggris dan } \\
\text { Matematika. }\end{array}$ & $\begin{array}{l}\text { (-) merasa tidak } \\
\text { kompeten dalam pelajaran } \\
\text { Bahasa Inggris dan } \\
\text { Matematika. }\end{array}$ & $\begin{array}{l}\text { (一) merasa pesimis dan takut } \\
\text { menghadapi ujian akhir sekolah dan } \\
\text { ujian nasional karena ia merasa } \\
\text { kesulitan dalam memahami pelajaran } \\
\text { Bahasa Inggris dan Matematika. }\end{array}$ \\
\hline $\begin{array}{l}\text { Bangga dan puas akan dirinya } \\
\text { sendiri. }\end{array}$ & $\begin{array}{l}(-) \text { merasa gagal } \\
\text { dalam hal } \\
\text { akademis. }\end{array}$ & - & $\begin{array}{l}\text { (-) merasa gagal dalam hal akademis } \\
\text { dan belum puas dengan dirinya terutama } \\
\text { terkait prestasi belajarnya. } \\
(-) \text { berkeinginan untuk berada di posisi } \\
\text { sepupunya yang berprestasi. }\end{array}$ \\
\hline $\begin{array}{l}\text { Lebih sensitif terhadap tingkat } \\
\text { kemampuan/kompetensi. } \\
\text { Mengabaikan umpan balik } \\
\text { negatif dan mencari umpan } \\
\text { balik mengenai kompetensi. }\end{array}$ & - & $\begin{array}{l}\text { ( }- \text { ) fokus terhadap infor- } \\
\text { masi negatif (sedih karena } \\
\text { dilabeli sebagai anak nakal } \\
\text { oleh teman-temannya). }\end{array}$ & $\begin{array}{l}\text { (-) lebih sensitif dan semakin minder } \\
\text { karena sering dibanding-bandingkan } \\
\text { dengan sepupunya terkait dengan nilai } \\
\text { di sekolah. }\end{array}$ \\
\hline $\begin{array}{l}\text { Menerima peristiwa negatif } \\
\text { yang dialami dan berusaha } \\
\text { memperbaiki diri. }\end{array}$ & - & - & $\begin{array}{l}\text { (一) merasa sedih dan merasa bahwa } \\
\text { dirinya sulit untuk dapat membaha- } \\
\text { giakan orang lain (terutama keluarga). }\end{array}$ \\
\hline $\begin{array}{l}\text { Lebih sering mengalami emosi } \\
\text { positif (senang, bahagia). }\end{array}$ & $\begin{array}{l}(-) \text { belum bisa } \\
\text { menyalurkan } \\
\text { emosi marah dan } \\
\text { cenderung } \\
\text { memendamnya. }\end{array}$ & $\begin{array}{l}(-) \text { cemas saat ditanya } \\
\text { oleh bibinya tentang } \\
\text { perilaku di sekolah. }\end{array}$ & $\begin{array}{l}\text { (-) merasa cemas ketika sedang } \\
\text { mengerjakan tugas Bahasa Inggris. } \\
\text { (-) seringkali mengalami emosi negatif } \\
\text { (sedih, marah, kesal). }\end{array}$ \\
\hline $\begin{array}{l}\text { Fleksibel. berani, dan lebih } \\
\text { mampu mengekspresikan diri } \\
\text { saat berinteraksi dengan orang } \\
\text { lain (spontan dan aktif). }\end{array}$ & $\begin{array}{l}\text { (-) berperilaku } \\
\text { ikut-ikutan orang } \\
\text { lain. }\end{array}$ & $\begin{array}{l}\text { (-) kaku dalam menjalin } \\
\text { interakasi dengan orang } \\
\text { lain (mengikuti teman). }\end{array}$ & $\begin{array}{l}\text { (-) cenderung memendam emosi } \\
\text { negatifnya. } \\
(-) \text { kurang spontan dan mengikuti } \\
\text { perilaku temannya atau sepupunya. }\end{array}$ \\
\hline $\begin{array}{l}\text { Berusaha untuk melakukan } \\
\text { sesuatu agar kapasitas dirinya } \\
\text { meningkat (lebih tumbuh dan } \\
\text { berkembang). }\end{array}$ & $\begin{array}{l}(-) \text { kurang me- } \\
\text { miliki aspirasi } \\
\text { untuk mencapai } \\
\text { tujuan. } \\
(-) \text { malas }\end{array}$ & - & $\begin{array}{l}\text { (-) merasa takut berbuat salah terutama } \\
\text { saat di depan paman dan bibinya. } \\
(-) \text { takut melakukan kesalahan ketika } \\
\text { mengerjakan tugas Bahasa Inggris dan } \\
\text { Matematika. }\end{array}$ \\
\hline Berani mengambil resiko. & - & $\begin{array}{l}\text { (-) tidak berani } \\
\text { mengambil resiko dan } \\
\text { takut berbuat salah di } \\
\text { depan paman dan bibinya }\end{array}$ & $\begin{array}{l}\text { (一) tidak berani bertanya dan menjawab } \\
\text { pertayaan guru pada pelajaran Bahasa } \\
\text { Inggris. }\end{array}$ \\
\hline $\begin{array}{l}\text { Bersikap positif terhadap orang } \\
\text { lain, kelompok, atau institusi. }\end{array}$ & $\begin{array}{l}(-) \text { nakal, jahil } \\
\text { terhadap teman. }\end{array}$ & - & $\begin{array}{l}(-) \text { merasa iri karena tidak dapat } \\
\text { berprestasi seperti sepupunya. }\end{array}$ \\
\hline Berpikir konstruktif (fleksibel). & - & & $\begin{array}{l}\text { ( }- \text { ) kaku dan tidak fleksibel ketika } \\
\text { mengerjakan sesuatu. Misalnya saat } \\
\text { mengerjakan ujian, subjek terkadang } \\
\text { berfokus pada soal yang sulit sehingga } \\
\text { soal lainnya tidak sempat dikerjakan } \\
\text { karena waktunya habis. }\end{array}$ \\
\hline $\begin{array}{l}\text { Mampu mengambil keputusan } \\
\text { dengan cepat dan yakin dengan } \\
\text { keputusan yang diambilnya. }\end{array}$ & - & $\begin{array}{l}\text { (-) mengikuti keputusan } \\
\text { orang lain dan tidak yakin } \\
\text { dengan keputusannya }\end{array}$ & $\begin{array}{l}\text { (-) mengikuti jawaban sepupunya } \\
\text { dalam mengambil keputusan. }\end{array}$ \\
\hline
\end{tabular}

Ket: - tidak terukur saat pengambilan baseline

Pada baseline ketiga, seluruh karakterisitk self-esteem tinggi menurut Rosenberg dan Owens (dalam Guindon, 2010) tidak tercapai pada diri subjek. Hasil ini menunjukkan 
bahwa karakteristik self-esteem subjek tergolong rendah. Penjelasan lebih rinci mengenai hasil ketiga baseline dipaparkan dalam Tabel 1.

Berdasarkan Tabel 1, hasil tiga baseline menunjukkan bahwa karakteristik self-esteem subjek tergolong rendah.

\section{PEMBAHASAN}

Berdasarkan hasil dan analisis penelitian, dapat disimpulkan bahwa self-esteem terbukti menurun, pada remaja awal laki-laki memiliki self-esteem rendah yang berkaitan dengan kompetensi diri dan berdampak pada beberapa aspek penting dalam perkembangannya, misalnya aspek akademis. Dengan hasil penelitian ini, peneliti menyimpulkan bahwa diperlukan penelitian lebih lanjut mengenai rancangan program intervensi untuk menangani permasalahan self-esteem yang terjadi pada remaja awal.

Hasil penelitian ini menunjukkan bahwa self-esteem terbukti menurun pada masa remaja awal. Hal ini sesuai dengan penelitian Bos, Muris, Mulkens, \& Schaalma (2006) yang mengemukakan bahwa terjadi penurunan yang drastis pada global self-esteem remaja. Selain itu, hasil penelitian ini juga menunjukkan bahwa permasalahan self-esteem rendah yang dimiliki oleh remaja awal laki-laki berkaitan dengan kompetensi yang rendah. Berbeda dengan penelitian yang dilakukan oleh Larasati (2012) yang menunjukkan bahwa self-esteem remaja awal perempuan yang berkaitan dengan penampilan fisik dan hubungan sosial. Hasil penelitian ini sesuai dengan penelitian yang dilakukan Larasati (2012) dan Harter (Mruk, 2006) yang menyebutkan bahwa self-esteem mempengaruhi dua jenis kelamin remaja. Hanya saja, self-esteem remaja perempuan lebih terkait dengan kepuasan untuk diterima dan dihargai secara emosional terutama terkait dengan penampilan fisiknya, sedangkan self-esteem remaja laki-laki lebih berkaitan dengan perkembangan kompetensi yang ditunjukkan melalui pencapaian prestasi.

Berdasarkan hasil penelitian ini, masalah self-esteem rendah yang dialami remaja awal berdampak pada prestasi akademisnya yang rendah. Hal ini membuat remaja memiliki pemikiran distorsi dalam dirinya, salah satunya global labelling yakni sering merasa cemas dan sering gagal dalam prestasi akademis di sekolah. Adanya pemikiran distorsi ini membuat remaja merasa belum puas dengan dirinya terutama terkait prestasi yang dimilikinya saat ini. Remaja dengan self-esteem rendah cenderung kurang menunjukkan usaha yang optimal untuk berprestasi di sekolah karena dia merasa tidak kompeten, malas, usaha dan daya juangnya masih kurang dalam belajar. Hal ini menunjukkan bahwa remaja memiliki pemikiran distorsi self-blame. Baldwin dan Hoffman (Guindon, 2010) mengemukakan bahwa remaja dengan self-esteem rendah sejak masa kanak-kanak mengalami banyak kesulitan pada masa remaja dan mengalami perasaan tidak mampu pada banyak bidang. 
Selain itu, kondisi remaja yang sering dibanding-bandingkan dengan teman sebaya atau orang terdekat yang memiliki prestasi yang lebih baik di sekolah, membuat remaja memiliki pemikiran distorsi personalization yakni remaja semakin merasa minder dan sering memiliki keinginan seperti sepupunya yang memiliki prestasi baik. Remaja dengan self-esteem rendah ini juga cenderung memiliki pemikiran overgeneralization karena ia menilai bahwa dirinya tidak mungkin untuk berada di posisi teman sebaya atau orang terdekatnya yang berprestasi. Adanya sikap dibanding-bandingkan dan adanya kritik negatif dari significant others membuat remaja memiliki pemikiran distorsi filtering yakni cenderung berfokus pada kritik negatif tersebut. Selain itu, sikap jahil yang dilakukan remaja dengan self-esteem rendah untuk mendapat perhatian dari keluarga, guru, dan teman-temannya membuat remaja mendapat label negatif dari guru, teman, dan keluarga. Label negatif ini membuat remaja memiliki pemikiran distorsi emotional reasoning. Remaja dengan self-esteem rendah sering mengalami emosi negatif, seperti kesal, marah, dan merasa tidak dapat membahagiakan orang lain karena ia merasa tidak berguna dengan prestasinya yang rendah; namun remaja cenderung memendam dan menghindar karena tidak berani mengungkapkannya.

Hasil penelitian ini menunjukkan bahwa adanya pemikiran distorsi dalam diri remaja dan kurangnya dukungan, kehangatan, harapan/ekspektasi, dan pola asuh yang berbeda dari keluarga, serta label negatif dari guru dan teman di sekolah inilah yang menguatkan remaja menilai negatif dirinya sehingga mengakibatkan remaja memiliki self-esteem yang rendah. Menurut Harter (Guindon, 2010), permasalahan self-esteem yang terjadi pada remaja disebabkan oleh adanya diskrepansi antara ideal-self dan actual-self. Hal ini membuat remaja menunjukkan perilaku yang ingin ditampilkan pada orang lain, hanya saja terkadang perilaku tersebut tampak dipaksakan (Wang \& Ollendick, dalam Larasati, 2012).

Penelitian mengenai preprogram atau pengambilan baseline untuk mengukur selfesteem pada remaja awal ini ditunjang oleh beberapa faktor keberhasilan yakni disesuaikan dengan prosedur pengambilan baseline menurut Martin dan Pear (2015). Terdapat enam langkah yang dilakukan dalam pengambilan baseline dalam penelitian ini. Langkah pertama adalah menentukan masalah dengan menggunakan istilah perilaku yang tepat untuk memperoleh suatu baseline yang reliabel (Martin \& Pear, 2015). Dalam penelitian ini, peneliti melakukan analisis kebutuhan untuk memperoleh gambaran permasalahan yang dialami oleh subjek. Analisis kebutuhan dalam penelitian ini dilakukan melalui pemeriksaan psikologis terhadap subjek serta wawancara subjek, wali, dan guru. Setelah mendapat gambaran permasalahan, peneliti melakukan tinjauan literatur untuk menentukan konstruk psikologi yang tepat sesuai dengan masalah subjek. Hasil tinjauan literatur menunjukkan bahwa masalah self-esteem merupakan konstruk yang sesuai dengan yang dialami subjek. 
Setelah menentukan masalah, langkah yang turut mendukung keberhasilan penelitian ini adalah menentukan prosedur pengambilan baseline yang memungkinkan untuk dilakukan oleh peneliti (Martin \& Pear, 2015). Prosedur pengambilan baseline yang dilakukan oleh peneliti adalah dengan melakukan wawancara terhadap subjek, wali, dan guru mengenai karakeristik self-esteem tinggi menurut Rosenberg dan Owens (Guindon, 2010). Hasil wawancara ini bertujuan untuk mengidentifikasi perilaku bermasalah yang dimiliki subjek (dalam hal ini self-esteem yang rendah), mengidentifikasi faktor yang menyebabkan self-esteem subjek menurun, mengidentifikasi konsekuensi atau dampak dari self-esteem yang rendah, serta mengidentifikasi perilaku yang ingin diubah oleh subjek dan diharapkan oleh wali serta guru.

Selanjutnya, langkah ketiga yang menjadi faktor keberhasilan penelitian ini adalah merancang prosedur perekaman yang memungkinkan peneliti untuk mencatat jumlah waktu yang dikhususkan baik untuk subjek, guru, maupun orangtua (Martin \& Pear, 2015). Dalam penelitian ini, peneliti melakukan wawancara pada subjek, wali, dan guru pada waktu dan tempat yang berbeda sesuai dengan yang disepakati. Hal ini dilakukan untuk membantu peneliti memperoleh data yang lengkap mengenai masalah self-esteem subjek.

Langkah berikutnya yang mendukung penelitian ini adalah memastikan peneliti telah menguasai teori mengenai perilaku target sebelum melakukan wawancara dan menerapkan prosedur perekaman, dan membuat grafik atau tabel data (Martin \& Pear, 2015). Dalam penelitian ini, peneliti melakukan tinjauan literatur kembali guna menguasai teori terkait self-esteem remaja sebelum melakukan pengambilan baseline, melakukan perekaman dari hasil wawancara, dan membuat tabel data untuk membandingkan hasil dari tiga baseline yang telah dilakukan. Proses pengambilan baseline yang dilakukan selama tiga kali dalam penelitian ini dilakukan untuk mendapatkan trend atau level data yang jelas. Hal ini terlihat dari hasil penelitian yang menunjukkan bahwa pada baseline pertama dan kedua terdapat enam karakteristik self-esteem tinggi yang tidak tercapai pada diri subjek, sedangkan lima karakteristik lainnya tidak terukur dalam baseline pertama dan kedua. Pada baseline ketiga, seluruh karakterisitk self-esteem tinggi menurut Rosenberg dan Owens (dalam Guindon, 2010) tidak tercapai pada diri subjek. Hasil ini menunjukkan bahwa karakteristik self-esteem subjek tergolong rendah. Pelaksanaan pengukuran dan pencatatan data pada kondisi baseline yang dilakukan selama tiga kali (desain A1, A2, A3) setelah terlihat level data diketahui secara jelas bertujuan untuk meningkatkan validitas dari penelitian (Sunanto, Takeuchi, \& Nakata, 2005).

Dari penelitian ini juga tampak bahwa meskipun terdapat beberapa faktor yang menunjang keberhasilan penelitian ini, peneliti menyadari bahwa terdapat juga faktor yang menjadi kendala dalam penelitian ini. Salah satu faktor yang menghambat penelitian ini adalah penggunaan instrumen yang hanya berfokus pada satu metode yakni 
wawancara saja sehingga pada beberapa karakteristik tidak terukur pada pengambilan baseline pertama dan kedua. Oleh karena itu, langkah berikutnya yang sebaiknya dilakukan setelah pengambilan baseline dalam penelitian ini adalah mengukur kembali tingkat self-esteem subjek dengan metode lain selain wawancara, misalnya melalui observasi, pemberian kuesioner, dan daftar cek perilaku. Salah satu kuesioner self-esteem yang dapat digunakan untuk remaja adalah Rosenberg Self-esteem Scale (RSES). Pengambilan data melalui kuesioner ini bertujuan untuk menyediakan cara yang cepat dan konsisten dalam mengumpulkan informasi, informasi yang diberikan oleh subjek dapat menjadi dasar untuk mendapat informasi lanjutan yang mungkin berguna jika terdapat beberapa fakta unik atau istimewa yang muncul pada diri subjek, dan untuk menghemat waktu dalam melakukan analisis data (Martin \& Pear, 2015).

Faktor berikutnya yang menjadi kendala adalah jarak waktu antara pengambilan data yang tidak sama antara pengambilan baseline pertama, kedua, dan ketiga. Jarak pengambilan baseline ini berkaitan dengan ketersediaan waktu subjek, wali, serta guru. Interval yang berbeda antar pengambilan baseline dapat mempengaruhi kondisi subjek, karena subjek bisa saja memperoleh pengalaman langsung yang mempengaruhi pembentukan kognisi dan perilaku sehingga tingkat self-esteemnya menjadi berbeda.

Selain itu, faktor berikutnya yang menjadi kelemahan dalam penelitian ini adalah lingkungan keluarga yang tampak kurang kondusif serta kurang mau membuka diri dan bekerjasama sehingga data yang diperoleh pada baseline pertama dan kedua terdapat karakteristik self-esteem subjek yang tidak terukur.

Martin dan Pear (2015) mengemukakan bahwa setelah pengumpulan data baseline selesai dilakukan maka subjek perlu diberikan suatu program intervensi. Dalam penelitian ini, mengingat masalah self-esteem subjek sangatlah berdampak pada pencapaian tugas perkembangannya maka intervensi untuk meningkatkan self-esteem subjek yang rendah sangat penting untuk segera dilakukan.

Berdasarkan hasil penelitian ini, maka perlu dirancang suatu program intervensi yang berguna bagi subjek yang tujuannya adalah untuk meningkatkan self-esteemnya. Guindon (2010) mengemukakan bahwa berdasarkan beberapa penelitian terdapat beberapa intervensi yang dapat dilakukan untuk meningkatkan self-esteem remaja, yakni pemberian dukungan sosial (social support), strategi/konseling individual dan kelompok (individual and group strategies), strategi kebugaran fisik (pshysical fitness strategies), strategi spesifik lainnya yang tergantung pada populasi (seperti terapi fokus, terapi narasi, terapi bermain, Eye-Movement Desentizitation and Reprocessing atau EMDR), serta strategi kognitif-perilaku (cognitive-behavioral strategies). Guindon (2010) mengemukakan bahwa strategi kognitif-perilaku (cognitive-behavioral strategies) terbukti efektif untuk meningkatkan self-esteem remaja. Salah satu teknik strategi-kognitif perilaku yang terbukti efektif untuk meningkatkan self-esteem remaja adalah teknik self-instructional training (Lange, Richard, Gest, Vries, \& Lodder, 1998; Lochman \& Curry, 2010). 
Selain itu, dengan adanya hasil penelitian ini, terdapat beberapa saran metodologis yang dapat dilakukan untuk pelaksanaan penelitian serupa bila dilakukan di kemudian hari. Penelitian selanjutnya sebaiknya memperhatikan interval pelaksanaan baseline sehingga kondisi subjek terkait pembentukan kognisi dan perilaku yang berpengaruh terhadap tingkat self-esteemnya terukur secara konsisten. Berkaitan dengan metode pengambilan data, penelitian selanjutnya sebaiknya menggunakan beberapa metode yakni tidak hanya melalui wawancara saja. Metode lain yang dapat dilakukan adalah menggunakan observasi, kuesioner, atau daftar cek perilaku. Pemberian metode lain dengan kuesioner atau daftar cek perilaku ini juga dapat mengatasi permasalahan ketika partisipan kurang terbuka atau kooperatif dengan metode wawancara. Dengan demikian, data yang diperoleh dalam pengambilan baseline ini dapat lebih efektif dan akurat sehingga memudahkan peneliti untuk mengambil kesimpulan.

\section{DAFTAR PUSTAKA}

Bordens \& Abbott (2011). Research Design and Methods A Process Approach $8^{\text {th }}$ Edtion. Mc Graw Hill.

Bos, AER, Muris, P., Mulkens, S., \& Schaalma, HP. (2006). Changing self-esteem in Children ad adolescents: A Roadmap for future Interventuons. Netherlands Journal of Psychology 62, 26-33.

Chung, J. M, Hutteman, R., Aken, M.A.G.V, \& Denissen, J. J. A. (2017). High, low, and in between: Self-esteem development from middle childhood to young adulthood. Journal of Research in Personality, 70 (2017) 122-133. Elsevier

Guindon, M.H. (2010). Self Esteem Across The Lifespan. New York: Routledge Taylor $\&$ Francis Group.

Herdiansyah, H. (2011). Metodologi Penelitian Kualitatif untuk Ilmu-ilmu Sosial. Jakarta: Salemba Humanika.

Lange, A., Richard, R., Gest, A., Vries, M., Lodder, L. (1998) The Effects of Positive Self-Instructions: A Controlled Trial. Cognitive Therapy and Research, Vol 22, No.3 1998.pp 225-236. Plenum Publishing Corporation.

Larasati W.P. (2012). Meningkatkan Self-esteem melalui Metode Self-Intruction. Tesis. Depok: Fakultas Psikologi Universitas Indonesia.

Lee, S.W. (2005). Encyclopedia of School Psychology. USA: SAGE Publication, Inc.

Lochman, J.E., \& Curry, J.F. (2010). Effect of Social Problem-Solving Training and SelfInstruction Training with Aggressive Boys. Journal of Clinical Child Psychology. 
Volume 39, 2009-2010. 159-164. Routledge, Psychology Press and Focal Press imprints. Diakses dari www.tandfonline.com

Maag, J.W. (2018). Behavior Management: From Theoritical Implications to Practical Applications $3^{\text {rd }}$ Edition. USA: Cengange Learning. Diakses dari www.books. google.com

Marotz, L.R. \& Allen, K. E. (2013). Developmental Profiles: Pre-Birth Through Adolescence. USA: Wadsworth, Cengange Learning.

Martin, G., Pear, J. (2015). Behavior Modification: What It Is and How to Do It. $10^{\text {th }}$ Edition. USA: Pearson

McClure, A.C., Tanski, S.E., Kingsbury, J., Gerrard, M., Sargent, J.D. (2010). Characteristic s Associated with Low Self-esteem Among US Adolescents. Academic Pediatrics; Jul/Aug 2010; 20, 4; ProQuest.

McKay, M. \& Fanning, P. (2016). Self Esteem ( $4^{r d}$ Ed). United States of America: New Harbinger Publications, Inc.

Mruk, J.C. (2006). Self Esteem Research, Theory and Practice: Toward A Positive Psychology of Self Esteem, $3^{\text {rd }}$ Ed. New York: Springer Publishing Co.

Shadish, W.R., Cook, T., Thomas, D. (2002). Experimental and Quasi-Experimental Designs for Generalized Causal Inference. USA. Houghton Mifflin Company.

Soufi, S., Damirchi, E.S., Sedghi, N., \& Sabayan, B. (2013). Development of Structural Model for Prediction of Academic Achievement by Global Self-esteem, Academic Self- concept, Self-regulated Learning Strategies and Autonomous Academic Motivation. Journal of Procedia - Social and Behavioral Sciences 114 (2014) 26-35. Elsevier.

Sunanto, J., Takeuchi, K., Nakata, H. (2005). Pengantar Penelitian dengan Subyek Tunggal. CRICED University of Tsukuba.

Sveningson, E. (2012). The Relation between Peer Social Status and Self-esteem in Middle Childhood. Thesis. Lunds Universitet: Institutionen for Psykologi. 